\title{
Hubungan sikap perawat dengan penerapan patient safety pada masa pandemi Covid 19
}

\author{
Usastiawaty Cik Ayu Saadiah Isnainy ${ }^{1}$, M.Ricko Gunawan $^{2 *}$, Rafika Anjarsari²
}

1Program Studi Diploma III Keperawatan Universitas Malahayati.

2Program Studi IImu Keperawatan Universitas Malahayati. *Email : muhrickogunawan@gmail.com

\author{
Abstract \\ Clinical nurses' attitude toward patient safety: application and results during Covid 19 pandemic
}

Background: Patient safety is an effort to reduce unnecessary injuries associated with health care to the minimum acceptable level. Patient safety incident report in Indonesia in 2009 were 114, 103 incident in 2010, 34 incident in 2011. The number of adverse events was $10.5 \%$ and a near miss incident was $6.15 \%$.

Purpose: known that relationship between nurses' attitude with patient safety application during the Covid-19 pandemic at public health center Pesawaran district in 2020.

Method: A quantitative study by survey analytical with cross-sectional design. The sampling technique using a questionnaire and taken by total sampling. The respondents of 40 clinical nurses at public health centre.

Results: Respondents who had positive attitudes were $32(80 \%)$, and who had negative attitudes was $8(20 \%)$. Respondents who had behavior of patient safety standard application with good categories were of $20(50 \%)$, and respondent with a poor category was of $20(50 \%)$ and based on the statistical result of ( $p$ value 0,008 ; $\mathrm{OR}=15,000)$.

Conclusion: There are relationship between clinical nurses' attitude toward patient safety: application and results during COVID-19 pandemic at the health center. Suggestions for health centre management to pay attention for patient during covid-19 pandemic and all staff nurses to follow the health protocol for Covid.

\section{Keyword : Clinical nurses; Attitude; Patient safety; Application; Covid-19 pandemic}

Pendahuluan: Keselamatan pasien merupakan sebuah upaya menurunkan cedera yang tidak perlu yang berhubungan dengan pelayanan kesehatan hingga ke tingkat minimum yang dapat diterima. Laporan insiden keselamatan pasien di Indonesia tahun 2009 sebanyak 114, tahun 2010 sebanyak 103, tahun 2011 sebanyak 34. Angka Kejadian Tidak Diharapkan (KTD) sebesar 10,5\% dan Kejadian Nyaris Cedera (KNC) sebesar 6,15\%.

Tujuan: Diketahui hubungan sikap perawat dengan penerapan patient safety pada masa pandemic covid $19 \mathrm{di}$ UPT Puskesmas Rawat Inap Kabupaten Pesawaran Tahun 2020.

Metode: Penelitian ini menggunakan desain penelitian Survey Analitik dengan menggunakan rancangan crosssectional. Teknik pengambilan sampel dalam penelitian ini menggunakan lembar kuesioner. Populasi dalam penelitian ini adalah seluruh perawat puskesmas rawat inap yang berjumlah 40 responden.

Hasil: Responden yang mempunyai sikap positif sejumlah $32(80 \%)$ dan responden dengan sikap negatif sejumlah $8(20 \%)$. Responden yang mempunyai perilaku penerapan standar keselamatan pasien dengan kategori baik sejumlah $20(50 \%)$ dan responden dengan tingkat perilaku tidak baik sejumlah $20(50 \%)$. Uji penelitian yang dilakukan menggunakan uji chi square dengan hasil ( $p$ value 0,$008 ; O R=15,000$ ).

Simpulan: Ada hubungan sikap dengan penerapan patient safety pada masa pandemi covid 19 di UPT Puskesmas Rawat Inap Kabupaten Pesawaran tahun 2020. Saran dari peneliti ini diharapkan untuk selalu menerapkan standar keselamatan pasien dalam pelayanan.

\section{Kata Kunci: Sikap; Perawat; Penerapan; Patient safety; Pandemi Covid-19}

\section{PENDAHULUAN}

Keselamatan pasien merupakan sebuah upaya menurunkan cedera yang tidak perlu yang berhubungan dengan pelayanan kesehatan hingga ke tingkat minimum yang dapat diterima. "Tingkat minimum yang dapat diterima (acceptable minimum)" merujuk pada pengetahuan yang dimiliki saat ini, sumber daya yang tersedia, dan konteks dimana pelayanan diberikan, dengan membandingkannya terhadap risiko jika tidak

\footnotetext{
Usastiawaty Cik Ayu Saadiah Isnainy', M.Ricko Gunawan ${ }^{2 *}$, Rafika Anjarsari

'Program Studi Diploma 111 Keperawatan Universitas Malahayati.

${ }^{2}$ Program Studi llmu Keperawatan Universitas Malahayati. *Email : muhrickogunawan@gmail.com
} 
dilakukan tindakan atau jika dilakukan tindakan lain. Secara sederhana, hal ini merupakan upaya pencegahan kesalahan dan kejadian yang tidak diharapkan pada pasien yang berhubungan dengan pelayanan kesehatan (Panesar, Carson, Salvilla \& Sheikh, 2017).

Keselamatan pasien merupakan masalah kesehatan masyarakat global yang serius. $\mathrm{Di}$ Eropa mengalami pasien dengan risiko infeksi $83,5 \%$ dan bukti kesalahan medis menunjukkkan $50-72,3 \%$. Rumah sakit di berbagai negara ditemukan KTD (Kejadian Tidak Diharapkan) dengan rentang 3,2 $-16,6 \%$. Data patient safety tentang kejadian nyaris cedera dan kejadian tak diharapkan di Indonesia masih jarang, insiden pelanggaran patient safety $28,3 \%$ dilakukan oleh perawat (World Health Organization, 2014).

Sikap dikatakatan sebagai suatu respon evaluative.Respon hanya akan timbul apabila individu dihadapkan pada suatu stimulus yang menghendaki adanya reaksi individual. Respons evaluative berarti bahwa bentuk reaksi yang dinyatakan sebagai sikap itu timbul didasari oleh proses evaluasi dalam diri individu yang memberi kesimpulan stimulus dalam bentuk nilai baik-buruk, positif-negatif, menyenangkan - tidak menyenangkan yang kemudian mengkristal sebagai potensi reaksi terhadap objek sikap (Puri, 2012).

Tujuh langkah menuju keselamatan pasien (patient safety) terdiri atas : membangun kesadaran akan nilai keselamatan pasien, memimpin dan mendukung staf, mengintegrasikan aktivitas pengelolaan resiko, mengembangkan sisitem pelaporan, melihatkan danberkomunikasi dengan pasien, belajar dan berbagi pengalaman tentang keselamatan pasien, dan mencegah cedera melalui implementasi sistem keselamatan pasien (Kementerian Kesehatan Republik Indonesia, 2017).

Berdasarkan data di UPT Puskesmas Rawat Inap Hanura Kejadian Tidak Diinginkan (KTD) pada tahun 2018 sebanyak 2 insiden, meningkat di tahun 2019 sebanyak 3 insiden yang secara keseluruhan terdiri dari kejadian pasien jatuh, sedangkan angka kejadian infeksi nosokomial masih tinggi dan belum memenuhi standar. Angka kejadian infeksi nosokomial pada tahun 2018 mencapai 7,30\%, sedangkan tahun 2019 meningkat menjadi $7,60 \%$ (Dinas Kesehatan Kabupaten Pesawaran, 2019).
Berdasarkan data di UPT Puskesmas Rawat Inap Tegineneng pada tahun 2019. Dilaporkan angka Kejadian Tidak Diharapkan (KTD) sebesar 10,5\% dan Kejadian Nyaris Cedera (KNC) sebesar 6,15\% (Dinas Kesehatan Kabupaten Pesawaran, 2019).

Berdasarkan data Puskesmas Rawat Inap Kedondong capaian keselamatan pasien tahun 2019 diketahui bahwa pada indikator pengkajian awal klinis yang terisi lengkap mencapai $50 \%$, kepatuhan CTPS dengan 6 langkah cuci tangan 80\% dan kepatuhan penggunaan APD 80\% (Dinas Kesehatan Kabupaten Pesawaran, 2019).

Hasil penelitian ini juga sejalan dengan penelitian sebelumnya di Rumah Sakit Pusri Palembang. Menunjukkan bahwa ada hubungan antara pengetahuan dan sikap perawat dengan pelaksanaan keselamatan pasien di Rumah Sakit Pusri Palembang dengan $p$ value 0,05 (Roswati, 2019).

Upaya penerapan patient safety sangat tergantung dari pengetahuan perawat.Apabila perawat menerapkan patient safety didasari oleh pengetahuan yang memadai, maka perilaku patient safety oleh perawat tersebut akan bersifat langgeng (long lasting).Seorang perawat dalam memberikan asuhan keperawatan harus memiliki pengetahuan yang benar,keterampilan, dan sikap untuk menangani kompleksitas perawatan kesehatan. Tanpa pengetahuan termasuk perawat tidak biasa menerapkan dan mempertahankan budaya keselamatan pasien.

\section{METODE}

Jenis penelitian Survey Analitik dengan menggunakan rancangan cross-sectional. Penelitian ini sudah lulus uji kelaikan etik dengan nomer surat No.1111/EC/KEP-UNMAL/VIII/2020 Universitas Malahayati. Teknik penelitian sampel menggunakan total sampling.Penelitian ini dilaksanakan di 3 Puskesmas Rawat Inap Kabupaten Pesawaran yaitu (Hanura,Kedondong dan Tegineneng). Alat ukur yang digunakan dalam penelitian ini berupa lembar kuisioner yaitu sikap dan penerapan patient safety dengan jumlah 60 soal, dimana pada kuisioner diisi oleh 40 responden yaitu perawat yang bekerja di ruang rawat inap.

Kuisioner sikap perawat berisi 30 soal yang menanyakan tentang sikap perawat dalam pelayanan dan melayani di ruang lingkup rawat inap yang akan dijawab oleh responden dengan

\footnotetext{
Usastiawaty Cik Ayu Saadiah Isnainy', M.Ricko Gunawan ${ }^{2 *}$, Rafika Anjarsari ${ }^{2}$

'Program Studi Diploma 111 Keperawatan Universitas Malahayati.

${ }^{2}$ Program Studi llmu Keperawatan Universitas Malahayati. *Email : muhrickogunawan@gmail.com
} 
jawaban menggunakan skala likert yaitu sangat setuju, setuju, tidak setuju dan sangat tidak setuju dengan skor 0-90.Sikap dikatakan Positif apabila responden menjawab pertanyaan dalam kuisoner skor $85-90$ dan negatif bila skor $<85$ (Setiyajati, 2014).

Sedangkan untuk penerapan patient safety terhadap semua tindakan keperawatan yang dilakukan perawat akan diberikan beberapa pertanyaan/validasi sesuai item yang ada dalam lembar kuisioner sebanyak 30 soal yang akan dijawab oleh responden dengan jawaban ya dan tidak sesuai dengan pertanyaan dan pernyataan terkait tindakan perawat terhadap penerapan patient safety sesuai dengan realita yang ada di puskesmas rawat inap, responden ini berjumlah 40 reponden rawat inap yang akan mengisi lembar kuisioner dengan cara memberi ceklis ya untuk tindakan atau pernyataan yang sesuai dan memilih ceklis pada kolom tidak untuk pernyataan yang dirasa tidak sesuai dengan responden dengan skor 0-30.Penerapan patient safety dikatakan kategori "baik" apabila responden menjawab pertanyaan dalam kuisoner skor 25-30 dan kategori "buruk" jika skor $<25$.

Penggolahan data menggunakan SPSS 13.Uji analisis yang digunakan adalah uji-square.Analisis Odds Ratio (OR) digunakan untuk menetapkan besarnya resiko terjadinya efek pada kasus tersebut.Analisa data menggunakan univariat dan analisa bivariat.

\section{HASIL}

Tabel 1. Karakteristik Demografi Responden ( $N=40$ )

\begin{tabular}{llccc}
\hline Demografi & & $\mathbf{n}$ & $\%$ & M $\mathbf{4 S D}$ \\
\hline Umur (Tahun)(Rentang 20 - 50) & & 40 & 100 & $31.40 \pm 5.86$ \\
Pendidikan & D3 & 30 & 75.0 & \\
& S1 + ners & 10 & 25.0 & \\
Sikap Perawat & Negatif & 8 & 20.0 & \\
& Positif & 32 & 80.0 & \\
Penerapan patient safety & Buruk & 20 & 50.0 & \\
& Baik & 20 & 50.0 & \\
\hline
\end{tabular}

Berdasarkan tabel 1 responden berusia antara $20-50$ tahun sejumlah 40 perawat dengan mean 31.40 dan Std.Deviation 5.865; berpendidikan D3 sejumlah 30 (75\%), yang mempunyai sikap positif dalam penerapan patient safety sejumlah $32(80 \%)$. Responden yang mempunyai perilaku penerapan standar keselamatan pasien dengan kategori "baik dan buruk" dalam penerapan patient safety masing-masing sejumlah 20 ( $50 \%$ )

Tabel 2. Hubungan Sikap Perawat Dengan Penerapan Patient Safety Pada Masa Pandemi Covid-19

\begin{tabular}{|c|c|c|c|c|c|c|c|c|}
\hline \multirow{3}{*}{ Variabel } & \multicolumn{4}{|c|}{$\begin{array}{c}\text { Penerapan Patient } \\
\text { Safety }\end{array}$} & \multicolumn{2}{|c|}{ Total } & \multirow{3}{*}{$\mathrm{P}$ value } & \multirow{3}{*}{$\begin{array}{c}\text { OR } \\
\text { (Cl 95\%) }\end{array}$} \\
\hline & \multicolumn{2}{|c|}{ Buruk } & \multicolumn{2}{|c|}{ Baik } & & & & \\
\hline & $n$ & $\%$ & $n$ & $\%$ & $\mathrm{~N}$ & $\%$ & & \\
\hline $\begin{array}{l}\text { Sikap Perawat } \\
\text { Positif }\end{array}$ & 15 & 37.5 & 17 & 42.5 & 32 & 80.0 & 0,008 & $\begin{array}{c}15.000 \\
(1.325-169.870)\end{array}$ \\
\hline Negatif & 5 & 12.5 & 3 & 7.5 & 8 & 20.0 & & \\
\hline
\end{tabular}

\footnotetext{
Usastiawaty Cik Ayu Saadiah lsnainy', M.Ricko Gunawan ${ }^{2 *}$, Rafika Anjarsari

'Program Studi Diploma III Keperawatan Universitas Malahayati.

${ }^{2}$ Program Studi llmu Keperawatan Universitas Malahayati. *Email : muhrickogunawan@gmail.com
} 
Berdasarkan tabel 2 menunjukkan bahwa dari 8 responden yang mempunyai sikap negatif dalam penerapan patient safety yang buruk sebanyak 5 $(12.5 \%)$ responden, dan $3(7.5 \%)$ responden mempunyai penerapan patient safety yang baik. Sedangkan dari 32 responden yang memiliki sikap positif dalam penerapan patient safety sebanyak $15(37.5 \%)$ responden memiliki penerapan patient safety yang buruk dan 17 (42.5\%) responden memiliki sikap positif dalam penerapan patient safety yang baik.Dari tabel diatas hasil dengan $P$ value $=0,008$ berarti $p<0.05$, maka Ha diterima (menerima hipotesa) dan Ho ditolak (hipotesa ditolak) sehingga dapat disimpulkan bahwa ada hubungan sikap perawat dengan penerapan patient safety.

Odds Ratio (OR) yang didapatkan dari perhitungan yaitu 15,000 artinya bahwa perawat yang memiliki sikap positif dalam penerapan pasien safety yang baik memiliki peluang 15 kali lebih besar dibanding perawat yang memiliki sikap negatif dalam penerapan pasien safety yang buruk.

\section{PEMBAHASAN}

\section{Sikap Perawat}

Berdasarkan hasil penelitian sikap perawat menunjukkan sebagian besar responden mempunyai sikap positif sejumlah 32 (80\%). Sedangkan yang paling sedikit adalah responden dengan sikap negatif sejumlah 8 (20\%). Sikap dikatakatan sebagai suatu respon evaluative. Respon hanya akan timbul apabila individu dihadapkan pada suatu stimulus yang menghendaki adanya reaksi individual. Respons evaluative berarti bahwa bentuk reaksi yang dinyatakan sebagai sikap itu timbul didasari oleh proses evaluasi dalam diri individu yang memberi kesimpulan stimulus dalam bentuk nilai baik-buruk, positif-negatif, menyenangkan-tidak menyenangkan yang kemudian mengkristal sebagai potensi reaksi terhadap objek sikap (Puri, 2012; Maringan,Pongtuluran \& Maria, 2017). Hasil penelitian ini sejalan dengan penelitian sebelumnya Di Ruang Akut Instalasi Gawat Darurat RSUP Prof.Dr.R.D.Kandou Manado.Menunjukkan bahwa responden yang memiliki sikapbaik berjumlah 18 orang $(58,1 \%)$, sedangkanresponden yang memiliki sikap kurangberjumlah 13 orang (41,9\%) (Lombogia, Rottie \& Karundeng, 2016).

Hasil analisa peneliti diperoleh bahwa sebagianresponden mempunyai sikap positif.
Responden yang memiliki sikap positif akan melakukan penerapan patient safety dengan aman sesuai dengan standar operasional prosedur dalam pelayanan.

\section{Penerapan Patient Safety}

Berdasarkan hasil penelitian penerapan safety menunjukkan bahwa sebagian besar responden mempunyai perilaku penerapan standar keselamatan pasien dengan kategori baik sejumlah 20 responden (50\%). Sedangkan yang paling sedikit adalah responden dengan tingkat perilaku buruk sejumlah 8 responden $(50 \%)$.

Keselamatan pasien (patient Safety) adalah bebas dari cidera fisik dan psikologis yang menjamin keselamatan pasien,melalui penetapan system operasional,meminimalisasi terjadinya kesalahan,mengurangi rasa tidak aman pasien dalam system perawatan kesehatan dan meningkatan pelayanan yang optimal (Hadi, 2016).

Penerapan keselamatan pasien ini didasari oleh kesadaran akan nilai keselamatan pasien, memimpin dan mendukung staf, mengintegrasikan aktivitas pengelolaan resiko, mengembangkan sisitem pelaporan, melihatkan danberkomunikasi dengan pasien, belajar dan berbagi pengalaman tentang keselamatan pasien, dan mencegah cedera melalui implementasi sistem keselamatan pasien (Kementerian Kesehatan Republik Indonesia, 2017; Harefa, 2019). Hasil penelitian ini sejalan dengan penelitian sebelumnya di Ruang Akut Instalasi Gawat Darurat RSUP Prof.Dr.R.D.Kandou Manado.Menunjukkan bahwa kemampuan patient safety dalam pengurangan resiko jatuh baik 16 responden $(51,6 \%)$ dan kurang ada 15 responden (48,4\%) (Lombogia, Rottie \& Karundeng, 2016; Baihaqi \& Etlidawati, 2020).

Hasil analisa peneliti diperoleh bahwa sebagian responden mempunyai penerapan patient safety baik. Responden yang mempunyai penerapan patient safety yang baik dapat mengurangi terjadinya resiko cidera dan kejadian tidak diinginkan saat melakukan pelayanan.Selain itu pada penelitian diperoleh nilai $p=0,008(p>0,05)$ hal tersebut menunjukkan ada hubungan yang signifikan antara sikap perawat dengan penerapan patient safety.

\section{Hubungan Sikap Perawat dengan Penerapan Patient Safety}

Berdasarkan hasil analisis menunjukkan bahwa ada hubungan yang signifikan antara sikap

\footnotetext{
Usastiawaty Cik Ayu Saadiah lsnainy', M.Ricko Gunawan ${ }^{2 *}$, Rafika Anjarsari

'Program Studi Diploma III Keperawatan Universitas Malahayati.

${ }^{2}$ Program Studi llmu Keperawatan Universitas Malahayati. *Email : muhrickogunawan@gmail.com
} 
perawat dengan penerapan patient safety. Hal ini didasarkan pada hasil uji chi square yang diperoleh $\rho$ value $0,008 \quad(\rho<0,05)$. Hasil penelitian menunjukkan bahwa 8 responden yang mempunyai sikap negatif dalam penerapan patient safety yang buruk sebanyak $5(12.5 \%)$ responden, dan $3(7.5 \%)$ responden mempunyai sikap negatif dalam penerapan patient safety yang baik. Sedangkan dari 32 responden yang memiliki sikap positif dalam penerapan patient safety buruk sebanyak $15(37.5 \%)$, dan $17(42.5 \%)$ memiliki sikap positif dalam penerapan patient safety yang baik.

Sikap dikatakatan sebagai suatu respon evaluative. Respon hanya akan timbul apabila individu dihadapkan pada suatu stimulus yang menghendaki adanya reaksi individual. Respons evaluative berarti bahwa bentuk reaksi yang dinyatakan sebagai sikap itu timbul didasari oleh proses evaluasi dalam diri individu yang memberi kesimpulan stimulus dalam bentuk nilai baik-buruk, positif-negatif, menyenangkan - tidak menyenangkan yang kemudian mengkristal sebagai potensi reaksi terhadap objek sikap.Faktor predisposisi yang mempengaruhi penerapan patient safety meliputi pengetahuan, sikap, kepercayaan, keyakinan, dan motivasi (Puri, 2012; Maringan,Pongtuluran \& Maria, 2017; Pratiwi, 2017).

Standar keselamatan pasien (patient safety) meliputi : hak pasien, pendidikan bagi pasien dan keluarga, keselamatan pasien dalam kesinambungan, penggunaan metode peningkatan kinerja untuk melakukan evaluasi dan peningkatan keselamatan pasien, peran kepemimpinan dalam meningkatkan keselamatan pasien, pendidikan bagi staf tentang keselamatan pasien dan komunikasi merupakan kunci bagi staf untuk mencapai keselamatan pasien (Kementerian Kesehatan Republik Indonesia, 2017; Harefa, 2019; Cahyono, 2018).

Hasil penelitian ini sejalan dengan penelitian sebelumnya di Ruang Rawat Inap RSUD Liun Kendage Tahun 2013. Menunjukkan bahwa ada hubungan pengetahuan dan sikap perawat dengan pelaksanaan keselamatan pasien (patient safety) di Ruang Rawat Inap RSUD Liun Kendage Tahun 2013 dengan $p$ value $=0,000 \quad(a<0,05)$ (Bawelle, Sinolungan, \& Hamel, 2013).

Hasil penelitian ini juga sejalan dengan penelitian sebelumnya di Rumah Sakit Pusri Palembang. Menunjukkan bahwa ada hubungan antara pengetahuan dan sikap perawat dengan pelaksanaan keselamatan pasien di Rumah Sakit Pusri Palembang dengan $p$ value 0,05 (Roswati, 2019; Arrum,Salbiah \& Manik, 2016). Hasil penelitian yang diperoleh adalah terdapat 15 responden yang memiliki sikap positif tetapi masih melakukan penerapan patient safety dengan kategori cukup, hal ini dikarenakan penerapan patient safety tidak hanya dipengaruhi oleh faktor predisposisi. Pada penelitian ini penerapan patient safety dipengaruhi oleh sarana dan prasarana yang ada, sehingga masih banyak responden yang melakukan penerapan patient safety cukup baik.

\section{SIMPULAN}

Berdasarkan distribusi frekuensi sikap perawat sebagian besar responden mempunyai sikap positif sejumlah $32(80 \%)$. Sedangkan yang paling sedikit adalah responden dengan sikap negatif sejumlah $8(20 \%)$.Sedangkan pada perilaku penerapan standar keselamatan pasien dengan kategori baik sejumlah 20 (50\%). Sedangkan yang paling sedikit adalah responden dengan tingkat perilaku tidak baik sejumlah 20 (50\%).Maka pada hasil penelitian ini ada hubungan yang signifikan antara sikap perawat dengan penerapan patient safety. Hal ini didasarkan pada hasil uji chi square yang diperoleh $\rho$-value $0,008(\rho<0,05)$.

\section{SARAN}

Pada pihak manajemen puskesmas dan dinas kesehatan terkait supaya lebih meningkatkan supervisi ke Puskesmas di bawah kendalinya agar penerapan patient safety benar- benar diterapkan oleh perawat sesuai protokol Covid. Komplikasi penularan Covid dapat dicegah semaksimal mungkin sehingga semua pasien di ruang rawat inap merasa aman dalam menjalani pengobatan terhadap penyakit yang dideritannya.

\section{DAFTAR PUSTAKA}

Arrum, D., Salbiah, S., \& Manik, M. (2015). Pengetahuan tenaga kesehatan dalam sasaran keselamatan pasien di rumah sakit sumatera utara. Idea Nursing Journal, 6(2), 1-6

Baihaqi, L. F., \& Etlidawati, E. (2020). Hubungan pengetahuan perawat dengan pelaksanaan keselamatan pasien (patient safety) di ruang

\footnotetext{
Usastiawaty Cik Ayu Saadiah lsnainy', M.Ricko Gunawan ${ }^{2 *}$, Rafika Anjarsari²

'Program Studi Diploma 111 Keperawatan Universitas Malahayati.

${ }^{2}$ Program Studi llmu Keperawatan Universitas Malahayati. *Email : muhrickogunawan@gmail.com
} 
rawat inap RSUD Kardinah Tegal. Jurnal Keperawatan Muhammadiyah.

Bawelle, S. C., Sinolungan, J. S. V., \& Hamel, R. (2013). Hubungan pengetahuan dan sikap perawat dengan pelaksanaaan keselamatan pasien (patient safety) di ruang rawat inap RSUD Liun Kendage Tahuna. Jurnal Keperawatan, 1(1)

Cahyono, A. (2018). Hubungan karakteristik dan tingkat pengetahuan Perawat terhadap pengelolaan keselamatan Pasien di rumah sakit. Jurnal IImiah WIDYA, 4(3

$\begin{array}{lll}\text { Dinas } \quad \text { Kesehatan } & & \text { Kabupaten } \\ \text { Pesawaran.(2019).Profil dari } & \text { Puskesmas } \\ \text { Rawat inap Hanura. } & & \end{array}$

$\begin{array}{crr}\text { Dinas } \quad \text { Kesehatan } & & \text { Kabupaten } \\ \text { Pesawaran.(2019).Profil } & \text { dari } & \text { Puskesmas } \\ \text { Rawat inap Tegineneng } & & \end{array}$

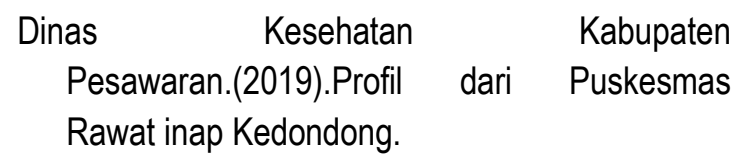

Hadi, I. (2016). Buku Ajar Manajemen Keselamatan Pasien. Deepublish

Harefa, E. I. J. (2019). Peningkatan Pelaksanaan Keselamatan Pasien Dalam Pelayanan Kesehatan di Rumah Sakit

Kementerian Kesehatan Republik Indonesia. (2017). Peraturan Menteri Kesehatan Republic Indonesia Nomor 11 Tahun 2017 Tentang Keselamatan Pasien.Diakses dari https://www.persi.or.id/images/regulasi/permen kes/pmk112017.pdf

Lombogia, A., Rottie, J., \& Karundeng, M. (2016). Hubungan Perilaku Dengan Kemampuan Perawat Dalam Melaksanakan Keselamatan
Pasien (Patient Safety) Di Ruang Akut Instalasi Gawat Darurat RSUP Prof. Dr. RD Kandou Manado. Jurnal Keperawatan, 4(2).

Maringan, K., Pongtuluran, Y., \& Maria, S. (2017). Pengaruh tingkat pendidikan, sikap kerja dan keterampilan kerja terhadap prestasi kerja karyawan pt. wahana sumber lestari samarinda. AKUNTABEL, 13(2), 135-150

Panesar, S., Carson, A., Salvilla, A., \& Sheikh, A. (2017). At A Glance Keselamatan Pasien dan Peningkatan Mutu Pelayanan Kesehatan. Jakarta: Erlangga.

Pratiwi, N. K. (2017). Pengaruh tingkat pendidikan, perhatian orang tua, dan minat belajar siswa terhadap prestasi belajar bahasa Indonesia Siswa SMK Kesehatan Di Kota Tangerang. Pujangga, 1(2), 31

Puri, P. K. D. (2012). Pengaruh tingkat pendidikan, pengetahuan, sikap dan terpaan iklan layanan masyarakat KB versi Shireen Sungkar dan Teuku Wisnu di TV terhadap perilaku KB pada wanita atau pria dalam usia subur. Interaksi: Jurnal IImu Komunikasi, 1(1), 46-56.

Roswati, A. (2019). Hubungan Pengetahuan Dan Sikap Perawat Dengan Pelaksanaan Keselamatan Pasien (Patient Safety) Di Rumah Sakit Pusri Palembang Tahun 2019. Masker Medika, 7(2), 323-331.

Setiyajati, A. (2014). Pengaruh Pengetahuan dan Sikap Perawat terhadap Penerapan Standar Keselamatan Pasien di Instalasi Perawatan Intensif RSUD Dr. Moewardi (Doctoral dissertation, UNS (Sebelas Maret University).

World Health Organization,(2014).Classification of patient-safety incidents in primary care. Retrieved from https://www.who.int/bulletin/volumes/96/7/17199802/en/

\footnotetext{
Usastiawaty Cik Ayu Saadiah lsnainy', M.Ricko Gunawan ${ }^{2 *}$, Rafika Anjarsari

'Program Studi Diploma 11 Keperawatan Universitas Malahayati.

${ }^{2}$ Program Studi llmu Keperawatan Universitas Malahayati. *Email : muhrickogunawan@gmail.com
} 